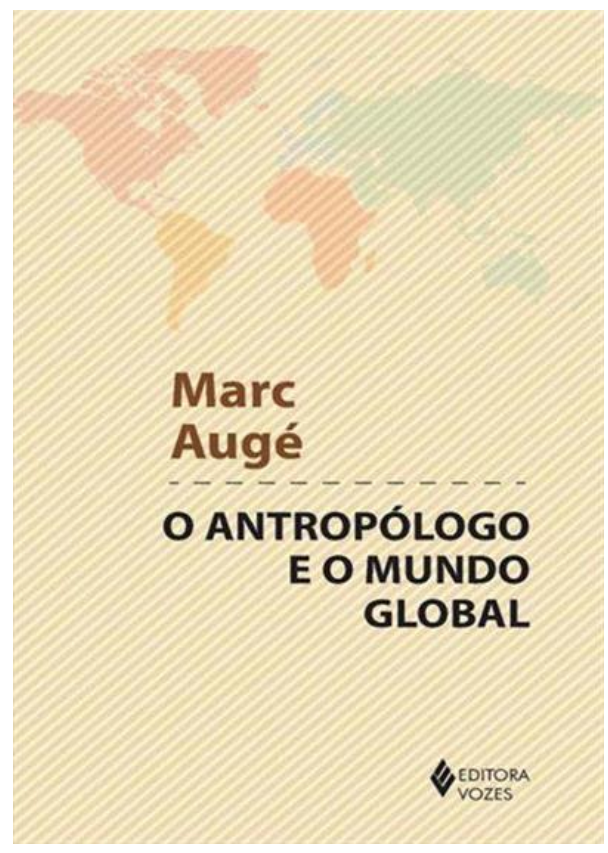

\title{
O antropólogo e o mundo global, de Marc Augé
}

Mauricio Pedro da Silva ${ }^{1}$

Antropólogo e etnólogo francês, Marc Augé é considerado, atualmente, um dos principais intelectuais europeus, tendo se tornado, entre outras funções que ocupou ao longo de sua carreira, presidente da prestigiada École des Hautes Études en Sciences Humaines. Autor de algumas dezenas de livros, publicou em 2013 duas obras fundamentais para a compreensão de suas ideias, uma delas traduzida para o português um ano depois.

Em L'impossible voyage: le tourisme et ses images, Augé discute a ideia de viagem (e de turismo) no atual mundo globalizado, criticando as agências de turismo que esquadrinham o mundo e transformam a natureza em produto, responsáveis "de la mise en fiction du monde, de sa déréalisation d'apparence - en réalité, de la conversion des uns en spectateurs et des autres en spectacle" (p. 15). Daí sua crítica ao turismo (não, às viagens), já que a diversidade do mundo tem pouco a ver, segundo ele, com o "kaléidoscope illusoire du tourisme" (p. 15), necessitando, portanto, que reaprendamos a viajar e, consequentemente, a ver.

Tratando de vários lugares que visitou (da Disneylândia ao Castelo de Luís II), o escritor critica, em especial, essa tendência atual à espetacularização do mundo ("nous

\footnotetext{
${ }^{1}$ Professor do Programa de Mestrado e Doutorado em Educação da Universidade Nove de Julho (UNINOVE). Endereço: Universidade Nove de Julho, PPGE. Av. Francisco Matarazzo, 612 Vila Maria 05001100 - São Paulo, SP - Brasil. E-mail: maurisil@gmail.com
} 
vivons une époque qui met l'histoire en scène, qui en fait un spectacle et, en ce sens, déréalise la réalité”, p. 31), levada a cabo pela publicidade do turismo, responsável por nos vender uma ficção, uma ilusão da realidade.

Em meio às considerações e críticas que faz, sugere a ocorrência do que costuma chamar de não lugar - "Le contraire du lieu, un espace où celui qui le traverse ne peut rien lire ni de son identité (de son rapport à lui-même), ni de ses rapports aux autres ou, plus généralement, des rapports entre les uns et les autres, ni, a fortiori, de leur histoire commune" (p. 106). São exemplos desse não lugar, para o autor, desde o balcão do aeroporto até uma butique de um posto de estrada, passando por outros espaços da paisagem periurbana, que 'assignent plutôt l'individu à la solitude et à l'anonymat dans la mesure même où ce 'paysage' se déqualifie, perdu entre un passe sans trace et un avenir sans forme" (p. 106).

Finalmente, relacionando o espaço citadino com a ficção e o imaginário, o autor lembra que a cidade forneceu dados aos principais romances dos séculos XIX e XX, afirmando, de modo peremptório, que "la ville est romanesque" (p. 131). Assim, conjugando memória e história, a cidade, segundo o autor, "existe par l'imaginaire qu'elle suscite et qui y fait retour, quéelle alimente et dont elle se nourrit, auquel elle donne naissance et qui fait renaître à chaque instant" (p. 133).

Já em $O$ antropólogo e o mundo global, o autor compara o trabalho do etnólogo antigamente, quando se estudava as relações sociais de um grupo restrito, com o de atualmente, cujo contexto é planetário, afirmando que, hoje em dia, toda etnologia é antropologia. Para o autor, uma das definiçõoes possíveis de cultura, nesse contexto, é a de uma "organização simbólica de um conjunto social" (p. 21), sendo o papel do antropólogo estudar uma determinada cultura.

Além disso, o autor lembra que, atualmente, assistimos a uma "superabundância de exposições de si próprio" (p. 32), que pode ser estudado num movimento de abordagem antropologica da contemporaneidade. É o que faz quando estuda os nãolugares da sobremodernidade (este último termo, forjado a partir do conceito de sobredeterminação de Freud e, depois, Althusser). Esses não-lugares são os "espaços da circulação, do consumo e da comunicação" (p. 38) contemporâneos. Para o autor, as acelerações tecnologicas do mundo contemporâneo modificam nossa relação com o tempo e com o espaço, sempre lembrando que "o espaço e o tempo são a matéria-prima de toda construção simbólica, de toda armação social e de toda elaboração individual: o 
arranjo do espaço e o emprego do tempo definem e resumem o essencial das atividades humanas desde os primórdios" (p. 40).

Augé lembra que a noção de paisagem depende, igualmente, das concepções de tempo e espaço: "as paisagens são culturais" (p. 49), afirma, dependendo do olhar de quem as observa. Nesse contexto, lembra que a paisagem sobremoderna é essencialmente urbana, e, retomando a questão da sobremodernidade, define: "a sobremodernidade (aceleração da história, encurtamento do espaço, promoção do indivíduo consumidor) corresponde a uma intensificação, não a um apagamento dos processos constitutivos da Modernidade" (p. 59). Com efeito, ressalta, enfatizando: "as paisagens do mundo atual, do mundo marcado pela aceleração do tempo, pelo encolhimento do planeta e pela individualização dos percursos são essencialmente paisagens urbanas ou em via de urbanização" (p. 63). Extendendo suas considerações para o conceito de não lugar, forjado em 1992, lembra não existir um não lugar no sentido absoluto do termo, mas que se trata de uma noção relativa: "em geral, a noção de não lugar é ambivalente e suscetível tanto de uma localização empírica como de uma definição teórica a qual nenhuma realidade corresponde de forma integral. Teoricamente, o não lugar é o absoluto da liberdade individual, um espaço onde não é possível ler nenhuma relação social: mas esse espaço de liberdade não existe, e, rigorosamente falando, trata-se de um espaço impensável, assim como é impensável toda solidão absoluta; a identidade sem alteridade, sem relação perde-se, já que carece de um minimum vital simbólico: é a morte, que só existe na lembrança dos vivos [...] O não lugar absoluto seria um espaço sem regras nem coerção coletiva de qualquer espécie: um espaço sem alteridade, um espaço de solidão infinita. $\mathrm{O}$ absoluto do lugar é totalitário, o absoluto do não lugar é a morte" (p. 67).

Autor que procura pensar sistematicamente nossa contemporaneidade, Marc Augé, por meio de suas obras, busca construir uma compreensão, pode-se dizer, heteróclita da realidade, já que - além de unir, de modo singular, os saberes antroplógico, sociológico e psicológico - procura mediar suas considerações pelo original conceito de não lugar, que, de certo modo, já se tornou "clássico" no mundo acadêmico das humanidades. 


\section{Para citar essa obra:}

SILVA, M. P. O antrópologo e o mundo global. In: RUA [online]. $\mathrm{n}^{\mathrm{o}}$. 23. Volume 1, p. 169 - 171 - e-ISSN 2179-9911 - Junho/2017. Consultada no Portal Labeurb - Revista do Laboratório de Estudos Urbanos do Núcleo de Desenvolvimento da Criatividade. http://www.labeurb.unicamp.br/rua/

Capa: Disponível em: < http://livrariascuritiba.vteximg.com.br/arquivos/ids/218632500-500/cap.jpg>

Laboratório de Estudos Urbanos - LABEURB

Núcleo de Desenvolvimento da Criatividade - NUDECRI

Universidade Estadual de Campinas - UNICAMP

http://www.labeurb.unicamp.br/

Endereço:

LABEURB - LABORATÓRIO DE ESTUDOS URBANOS

UNICAMP/COCEN / NUDECRI

CAIXA POSTAL 6166

Campinas/SP - Brasil

CEP 13083-892

Fone/ Fax: (19) 3521-7900

Contato: http://www.labeurb.unicamp.br/contato 